\title{
The Role and Limits of Representative Democracy: An Analysis from Joseph Schumpeter, Robert Dahl, and Anthony Downs
}

\author{
Jochua Abrão Baloi \\ Faculty of Ethics, Human and Legal Sciences of the University of Saint Thomas of Mozambique, Maputo, Mozambique \\ Email address: \\ jbaloi@yahoo.com.br \\ To cite this article: \\ Jochua Abrão Baloi. The Role and Limits of Representative Democracy: An Analysis from Joseph Schumpeter, Robert Dahl, and Anthony \\ Downs. Journal of Political Science and International Relations. Vol. 2, No. 4, 2019, pp. 79-85. doi: 10.11648/j.jpsir.20190204.11
}

Received: September 11, 2019; Accepted: October 7, 2019; Published: October 31, 2019

\begin{abstract}
This article comes about with the objective of analyzing in a comparative way the role and limits of representative democracy in the perspective of Joseph Schumpeter, Robert Dahl and Anthony Downs. In practice, it seeks to understand the ideas launched by these three theorists in the quest for a perception of what will become a democracy and its importance in the formation and constitution of the modern democracies. The central argument presented in this article is that in a truly democratic political system, popular participation is an essential element for the construction and execution of political actions. J. Schumpeter conceives democracy as a method that societies use to elect their representatives. R. Dahl conceives it as a polyarchy where both, the degree of incorporation of individuals and the level of institutionalization must be maximized and, A. Downs conceives democracy as a type of government where there should be fair and periodic elections, and one or more parties must compete for government control. Therefore, it is by analyzing the political thinking regarding the power and the representative democracy of these theorists that one perceives how the State left its natural character, thus assuming its civil personality, through the formation of the social contract.
\end{abstract}

Keywords: Democracy, State, Government, Polyarchy

\section{Introduction}

This article discusses the role and limits of representative democracy from the perspective of Joseph Schumpeter (1883-1950), Robert Dahl (1915-2014) and Anthony Downs (1930-), taking as a research focus their works, "Capitalism, Socialism and Democracy", "A Preface to Democratic Theory" and "An Economic Theory of Democracy", respectively.

This article also shows that for Schumpeter, democracy is conceived as a method that societies use to elect their representatives, i.e, individuals have the power to decide through competition and popular vote. In any definition of democracy as a form of government, participation appears as an essential element. Therefore, democracy not only guarantees freedom for every citizen to run for power, but also regulates the struggles for that power.

It is in this sense that Schumpeter argues that in today's democracies, there are elites who make an institutional arrangement in order to arrive at political decisions, and that individuals hold power through competition for popular vote. In their view, the elites have a political rationality and, therefore, they are the only ones who can make decisions, and it is up to society to elect them by voting. Thereafter, "if classical elitists were looking for a way to deny democracy, while much to the contrary grudgingly tolerate it, Schumpeter presented it as a defensible and desirable regime of government from an elitist perspective" [1].

From Dahl's perspective, democracy is a polyarchy where one should maximize the degree of incorporation on the one hand and the level of institutionalization on the other hand. These elements contribute to the understanding of his democracy as an elitist by giving participation a leading role in political decision-making process.

Thus, for Dahl, a stable government requires competition and political participation, and society must be founded on democratic institutions. The existence of democratic institutions is essential for the development of a polyarchy, 
which requires the responsiveness of the rulers to the preferences and / or interests of the citizens. Consequently, Dahl "places greater emphasis on participation, giving citizens a more active role. Polyarchy, therefore, cannot be understood as purely proceduralist" [2].

Downs conceives a democracy as a type of government where there must be fair and periodic elections, and one or more parties must compete for government control. These elements lead to consider that he has a pluralistic conception of power.

Using the model of economic theory of democracy, Downs considers that individuals possess instrumental rationality and that they maximize their preferences. Therefore, his democratic thinking is a reflection so that citizens must have sufficient information about government actions, and they must evaluate their actions, thus avoiding manipulation of economic and social policies. In Downs perspective, "democracy is characterized sometimes as a mechanism for guaranteeing peaceful competition among elites for control of the state apparatus, sometimes as an instrument for aggregating pre-political preferences" [3].

Therefore, while in Schumpeter democracy is conceived as a political method of selecting rulers, in Dahl it is a polyarchy. Therefore, a full realization of the founding principles of democracy, where the right to vote extends to the whole population and that political competition involves distinct groups, and in Downs, democracy is an important method for gaining the stability for rationality.

The methodological construction that guides this article involves a symbiosis of several methods (Qualitative, Monographic, Bibliographic), combining them with the reflexive hermeneutic for the effective reach of the theoretical and historical reference on the conception of democracy in Schumpeter, Dahl and Downs.

This article is divided into three parts, besides the introduction and conclusion. In the first, a theoretical approach to the conception of democracy in Schumpeter, Dahl and Downs is presented. Then is discussed the subtleties that underlie their ideals of democracy, presenting the similarities and differences among them, and finally are presented the contribution of their thoughts to the constitution and formation of modern democracies.

\section{The Conception of Democracy in Schumpeter, Dahl and Downs: A Literature Review}

The book "Capitalism, Socialism and Democracy" (1961) by Joseph Schumpeter opens in the world of democracy theorists, the elitist theory that is in fact, a critique of the traditional theory of democracy of the eighteenth century that had as its greatest exponent, Jean- Jacques Rousseau (17121778).

Starting from the conception that democracy is not an end in itself, since it can lead to dictatorship, but rather a method of selecting the rulers by way of elections, democracy in their view is a government of the elected elites.

Thus, Schumpeter considers democracy as a political method, i.e, "a certain kind of institutional arrangement to arrive at a political decision (legislative or administrative) and therefore incapable of being an end in itself, unrelated to the decisions it will produce under certain historical conditions" [4].

With this argument, it is clear that the institutional arrangement is aimed at achieving the common good, and only the people have the ability to decide through elections, the choice of individuals capable of representing their general will.

Regardless of democracy as a political or democratic method, Schumpeter states that this method is important since, individuals acquire the power to decide through a competition, that presupposes free votes of the population. These elements lead to realize that Schumpeter conceives an explanatory and / or elitist theory of democracy.

Therefore, in this competition there is an idea of leadership that is the criterion used to distinguish democratic from undemocratic governments. Thus, the electoral method is considered essential because it is the only method available to communities of any size in conducting competition within democratic regimes [5].

Therefore, in the "Schumpeterian version, the electoral process fulfills a similar role of society's establishment pact; it is the moment of transferring power from isolated individuals to the rulers. From then on, it is up to the citizen to have the duty of obedience, a freely consented obedience, because it has born of a presumed act of will" [6].

As for voters in this perspective, they do nothing but they choose a government or leader, and when he does not match their wishes, he is dispossessed. This is why some conditions are required for the success of the democratic method. The first condition advanced by Schumpeter is tha "the human material of politics (the members of the political machine, those who are elected to serve in parliament and attain ministerial posts) are of sufficiently high quality. This means more than the existence of a sufficient number of individuals with the necessary moral qualities and standards" [4].

Despite the existence of highly qualified politicians, this presupposes the exercise of politics as an activity by vocation. This idea of the exercise of politics as a vocation joins the who lives for politics, transforms it in the end of his life. Because the exercise of this activity allows him to find either the inner balance and express personal value, putting himself at the service of a cause that gives meaning to his life. This is a financially stable man and does not depend on remuneration for his political activities, i.e, he makes politics a vocation and not an end in itself [7].

The second condition for the success of the democratic method is to limit the effective reach of political decision, i.e, the real field of political decision-making should not be too long, since if the government wishes to address all issues concerning society, there is a serious risk of producing "legislative aberrations" [5]. In view of this finding, "the field of action not only depends, for example, on the type and 
quantity of issues that can be successfully resolved by a government subject to the stresses of an incessant struggle for its political survival. It also depends, at any time or place, on the quality of its men who make up the government, the kind of political machine and the public opinion framework to work with" [4].

The third condition still pointed out by him in this sense of the success of the democratic method is the availability of the services of a well-trained bureaucracy, of good standing, of tradition, and endowed with a strong sense of duty. This means in part that, "it is not enough for the bureaucracy to be efficient in administering current affairs and competent to give advice. It must be strong enough to guide and, if necessary, instruct the politicians who direct the ministries. To do so, it is necessary to create its own principles and be sufficiently independent to comply with them. In short, it must be a power in its own right. In fact, though not formally, appointments, tenure, and promotions must depend largely within the bureaucratic regulations that politicians themselves hesitate to violate - on their own concepts as a group" [4].

The ultimate condition for the success of this method is a democratic self-control, meaning that all major groups in society must be willing to accept governmental measures based on the law. Voters and parliamentarians should not take an uncompromising stance of opposition to any measure from the government, but should have a dose of tolerance on the part of political protagonists $[4,5]$.

Regarding the democratic elitism proposed by Schumpeter, he conceives a democracy as a regime, where the people have the choice or not of persons designated to govern, that is, these people are elected with the support of the electorate. In writing the book "Capitalism, Socialism and Democracy", he saw in these systems no incompatibility, but a complementarity, although he said that democracy emerged at a time when capitalism was consolidated, and this has sometimes led to the capitalist forces provoked some misfortunes to the democratic method.

Because of this, for Schumpeter, the organized capitalist interests can greatly deviate from democratic principles and methods, i.e, there are some means that are generally used to hinder the functioning of democratic leadership. The standards of capitalism compel many groups in society not to abide by the rules of the democratic method, putting it at risk. According to the author, socialism that works in order to maintain a certain unity in the collective could use the democratic method more effectively than is practiced in capitalism $[4,5]$.

Generally, much of what the classical theory of democracy thought, Schumpeter conceives it as a government for the people, which is exercised by political elites competing in the political market for voter preference. Although competition in the political market is as imperfect as it is in the economic market, political parties and voters act in the political market in a similar way to business and consumer activity in the economic market. Therefore, voting is the key element in the purchase of political goods offered by parties to voters, and political parties aim to gain and maintain power.

Robert Dahl, was known as one of the most studious of democracy when he published in 1956 his book "A Preface to Democratic Theory", where he intends to extend Schumpeter's elitist theory, proposing polyarchy, which he considered more suitable for modern societies.

Dahl's democratic theory is summarized in the sense that "the resources that contribute to power are distributed among different groups. Power is shared between government groups and external interests that put pressure on them. This approach provides a detailed description of decision-making processes and analysis of the individual influences of groups and / or organizations on political processes" [8].

These elements contribute to the conception of its democracy as a polyarchy, i.e, a modern type of democratic government, in which is only possible in pluralistic societies, where the decentralization of power is presupposed, and where citizens can group freely to represent their interests in the political process.

Dahl, in his work "The Concept of Power" conceives power as a relationship between people, where there is one who commands and one who obeys, i.e, A has power over B, as A leads B to do something, that otherwise he wouldn't do. Therefore, the actors whose preferences prevail in conflicts over key political issues are those who exercise power in a political system. These ideas justify the premise that power is a relationship between people where one commands and the other obeys [9].

In modern pluralistic democracies, the representative democracy proposed by Dahl is the only possible alternative to the exercise of collective sovereignty, i.e, in this democratic government, there is a need to ensure representativeness in political decisions. Therefore, Polyarchy would be the full realization of the founding principles of democracy.

In this sense, how responsive a political system is more reasons it has to be called a polyarchy. Therefore, to appreciate the ability of the political system or government to respond in the long term, three minimum conditions must be met. All citizens must have three unrestricted opportunities, i.e, they must develop preferences, making those preferences known, through individual and collective action to their fellow citizens and the government, and finally these preferences themselves must have the same weight in government policy [10].

Despite better clarifying the concept of polyarchy in Dahl, polyarchy is characterized by political regimes with low levels of coercion, high levels of persuasion and a relative autonomy of individuals with regard to constituted power. Such autonomy will result in the mobilization of individuals or groups for political participation. Polyarchic democracy is "a political system endowed with essential characteristics as: officials are often peacefully elected in clean elections where there is no coercion; free, fair and frequent elections; freedom of expression; diversified sources of information, i.e ensuring citizens' rights to have alternative sources of information that are not monopolized by governments and / 
or any other group; autonomy of individuals to form associations and inclusive citizenship" [8].

These elements lead to the conclusion that in Dahl, to measure the degree of democracy, one must first analyze the degree of political participation of the population in political competitions, and then ensure the institutionalization of the norms that should regulate the conflicts arising from competition. From Dahl's perspective, in a participatory democracy, political power is legitimized through political participation through representative voting elections.

This perspective is criticized, since "the elitist approach to power is based on the idea that in every human institution, there is an orderly system of power, a 'power structure' that is an integral part and a reflection of organizational stratification. In this postulate, pluralists emphatically reject and, from our point of view, correctly - based on the fact that nothing categorical can be assumed about power in any community. [...] indeed, there seems to be a subliminal notion among pluralist researchers that on top no one dominates in a city" [11].

This conclusion leads to the realization that these authors did not agree with Dahl's conclusions, and thus attest that the examination of power could not be restricted to key decisions or effective behavior. There is not only two faces of power because there is a face of the sociological tradition which gave rise to the elitist current, and which postulates the existence of power in the communities. There is other face of the political tradition, which is the mother of pluralist current that questions the existence of the ruling elites in communities and institutions. There is also in this perspective the face of leaders and the governed, which is the invisible face of power, regarded as the Third State [12].

The term democracy in Dahl's perspective is regarded as a political system that has, in its characteristics, the quality of being entirely or almost entirely responsive, i.e, which meets all citizens' preferences [5].

For a government to remain responsive for some time the preferences of its citizens, considered politically equal, all citizens "must have full opportunities to formulate their preferences. They must express their preferences to their fellow citizens and the government through individual and collective action, and should have their preferences equally considered in the conduct of the government, that is, considered without discrimination arising from the content or source of the preference" [13].

In this responsiveness of democracy, "Dahl understands it in two dimensions: public contestation and inclusiveness. Therefore, in the process of the progressive expansion of these two elements, he gives the name of democratization. The right to vote in free elections participates in both dimensions, because this right stimulates public contestation and at the same time makes the regime inclusive with the significant proportion of voting people. Thus, public contestation and inclusiveness become two criteria for the classification of political regimes" [5].

This argument leads to the creation of the conclusion that democracy in polyarchy is an unreachable ideal, which is why Dahl thinks of democracy on two axes: participation and inclusion on the one hand, competition, and liberalization on the other.

On this path, when there are two hegemonic regimes of precarious contestation and inclusiveness moving towards a polyarchy, this means that there is greater contestation and inclusion. However, for Dahl in polyarchy, there are more individuals, interest groups whose preferences should be taken into account when making political decisions, because of the greater participation of people. This ends up creating new possibilities for conflict because of the rulers being susceptible to substitution by the groups incorporated in the political process $[5,13]$.

Anthony Downs is known as the theorist of the pluralist theory of power and democracy, using the model of the economic theory of democracy to say that agents possess instrumental rationality since they know how to maximize and order their preferences.

In his book "An Economic Theory of Democracy", he seeks to explain the main features of politics in whatever democratic state, that is, to demonstrate that political parties and voters act rationally in pursuit of certain clear goals, which gives its theory its explanatory power.

To act rationally from the perspective of Downs is to have conscious action that is efficiently designed to achieve certain economic or political ends. Therefore, the government pursues some objectives taking as conditions, the existence of a democratic political structure that guarantees the existence of opposition parties, a favorable climate of varying degrees of uncertainty and the existence of rational voters.

To support this idea, "the rationality thus defined refers to processes of action, not to their ends or even their successes in attaining the desired ends. It is well known that rational planning sometimes produces results inferior to those obtained by pure luck. In the long term, we naturally expect a rational man to perform better than an irrational man does, ceteris paribus, because random facts are neutralized and efficiency triumphs over inefficiency. However, since behavior in our model cannot be tested by its results, we apply the term rational or irrational to action processes only, that is, to means. Of course, some intermediate means are themselves means for ultimate ends. The rationality of the former we may judge, but the evaluation of the latter is beyond our scope" [14].

The model of the pluralist conception of power proposed by Downs is intended to provide a rule of behavior for democratic government and to observe the implications arising from it. In abstraction from the real world, Downs proposes a society composed by citizens, rulers and government models. Therefore, for him, government is essential for the existence of an economy and in this case, there is no possibility of a satisfactory rule of conduct, which is why democratic governments are rationally to maximize political support.

In this position, Downs attests that "he considers himself a democratic government where society has the following 
conditions: a single party (or coalition of parties) is chosen by popular election to manage the governing apparatus. These elections are held at periodic intervals, the duration of which cannot be altered by the ruling party acting alone. All adults who are permanent residents of society are normal, and act in accordance with the laws of the land and are eligible to vote in each of these elections. Each voter may cast one and only one vote in each election. Any party (or coalition) that receives the support of a majority of voters has the right to assume the powers of government until the next election. Losing parties in an election may never attempt, by force or any illegal means, to prevent the winning party (or parties) from taking office. The ruling party never attempts to restrict the political activities of any citizens or other parties, as long as they do not attempt to overthrow the government. There are two or more parties competing for control of the governing apparatus in every election" [14].

Therefore, the democratic government seeks for Downs rational means to remain in power, i.e, it aims to achieve political rationality from an economic point of view, where deliberate political decisions are thought not only in terms of costs and benefits, but also according to preferences in order to remain in power through reelection.

Thereby, democracy is regarded as a political system that has certain characteristics, where political parties formulate policies strictly as a means of winning votes. Thus, they do not seek to gain office to pursue certain preconceived policies or to serve any specific interest group; instead, they formulate policies and serve interest groups in order to gain office [15].

Thus, its social function, which is to formulate and execute policies when in power, is realized as a byproduct in the sense of achieving the income, power and prestige of being in power. These arguments lead to the conclusion that from the perspective of Downs, in a democracy the government always acts to maximize the votes. Moreover, in a truly democratic society, government actions must be both political and economic, which led Downs to come up with an economic theory of political action in a democracy.

\section{Similarities and Dissimilarities Between the Conception of Democracy in Schumpeter, Dahl and Downs}

Studies exists that completely oppose the politicaldemocratic thinking of Schumpeter, Dahl and Downs, however, in relation to the point analyzed in this article, that is, about representative democracy. The opposition is tenuous, since there are adverse political positions relatively to the maintenance or not of democracy and / or power, since Schumpeter starts from an explanatory conception of power, Dahl from an elitist conception of power and Downs from a pluralist conception of power.

The three theorists start from a specific conception of democracy and then draw their conclusions. In this sense, unlike Schumpeter, Dahl conceives of participation as an essential element in the field of political decision-making. However, both come closer when they conceive that this field of political decision-making is a space of competition for political power. Downs, using the economic theory of democracy, states that agents (candidates, parties and voters) have an instrumental rationality, as they maximize and order their preferences, and their behavior can be predicted.

The democratic model proposed by Schumpeter is an institutional system in which individuals acquire the power to decide in accordance with the competitive struggle for voter votes. For him, the starting point for the democratic ideal is the existence of competition for people's support in political affairs, and the competitive struggle for leadership presupposes free competition for the vote. To this end, the people must freely choose their representatives, thus constituting the political government.

These elements lead to the perception that in Schumpeter the voter acts irrationally, since they do not have enough knowledge to make decisions on political issues, that is, their knowledge is limited, although there is in society some democratic elite, with a rationality..

Thus, there are some conditions for a democracy to function properly, such as, the existence of competent leaders with morally acceptable qualities and standards; the existence of a well-trained bureaucracy that has a sense of duty and teamwork and has self-control. Therefore, if one of these characteristics is not fulfilled, its democracy will not work and if it does, it will be disabled, as it will not respond to the structuring principles of society [4].

Political participation in Dahl is not reduced to the actions of individuals; on the contrary, participation in his polyarchic theory is linked to political associations, where individuals participate through institutions and never outside them. These elements contribute to the dissimilarity in Schumpeter and Dahl's thinking in devising, Schumpeter, a pessimistic assessment of popular participation in democracies, and Dahl in attaching great importance to participation.

However, Downs states that political participation is measured by voting, as the rational citizen makes his decision by stopping the gains and losses. By participating politically through voting, Downs argues that citizens have feedback that necessarily depends on the "benefits they get from democracy; how much they want a specific party to win; how close they believe the election is; and how many other citizens they believe will vote "[14].

Therefore, both Dahl and Downs also consider citizens rational, although they are not entirely rational, as they seek to minimize costs and increase benefits, yet individuals have different preferences and interests, so they are grouped into political associations and parties.

Thus, in their theories of democracy, these theorists had different concerns regarding to the competition between groups for political power. As a conditio sine qua non of polyarchy, government responsiveness, i.e, government's ability to meet citizens' preferences, Dahl was more concerned with democratizing democracy and Schumpeter with how it works [4, 13]. 
In this sense, political power, that is, the government is the one that makes the decisions and not the citizens, since they and the political parties are logically two distinct groups. In Downs, therefore, political parties, individual citizens, and interest groups, in their model, are the ones who make the political decisions, which differs from Schumpeter's model, where rationality is held only by political elites and not by the voters. This position leads to the conception of the voter as rational, i.e, he is able to direct his actions in function of a desired objective [14].

Therefore, democracy is a political system that allows rivalries or competition between a government and its opponents [13]. Thus, the essential characteristic of democracy in its model is linked to the continued responsiveness of government to the preferences of its citizens, in the production of public policies, for political participation and representation, and that all are politically equal. These factual elements lead to the formulation that, in Dahl, the model of his polyarchy consists on the existence of democratic institutions that act as instruments of protection for the governed and that the political participation of citizens for the functioning of democracy is fundamental.

\section{The Contribution of Schumpeter, Dahl and Downs Thought to the Formation of the Modern Democracies}

The modern approach to democracy is marked by an antipathy in several countries regarding to the functioning of representative democracy, although this model has not been overcome in political practices. Thus, Schumpeter, Dahl and Downs are among the various authors who have contributed greatly to the empirical approach to democracy.

The ideal models of representative democracy today are realized through the diversity of institutions that seek to create important public policies that must be formulated by all members elected by the people. These institutions have certain characteristics, such as free, fair and periodic elections, freedom of expression and association, which are ideals of whatever democracy.

Talking about the contribution of the thinking of Schumpeter, Dahl and Downs, and in particular addressing the conception of democracy and power is an essential issue for understanding not only the modern democracy but also the modern state. Therefore, it is by analyzing the political thinking regarding the power and representative democracy of these theorists that one perceives how the state left its natural character, thus assuming its civil personality, through the formation of the social contract ${ }^{1}$.

Schumpeter's thinking, regarded as an elitist theory of democracy, considers the democratic method to be one that is linked to the free competition between potential leaders for

1 In the modern state, individuals are considered as holders of rights and duties, that is, they are considered as citizens. Therefore, it is based on a formation that, in the present century, man within the state is a conditio sine qua non for the guarantee of justice and rights. the electorate's vote. Therefore, such competition takes place between professional politicians, since democracy means that the people have the ability to accept or reject the persons designated to govern it [4].

These lessons lead Schumpeter to be regarded as a contributing author and a major contributor to the debate on modern democracy, which is regarded not as an end in itself but as a method for reaching political decisions. Therefore, taking democracy as a method, the political arena in Schumpeter is now regarded as an economic marketplace, where elites compete for voter voting and the elections of people's representatives are a process that legitimizes the democratic process.

On the other hand, Dahl's thinking is also essential in the formation, constitution and consolidation of modern states, since he proposes the use of economic rules as a reference for a rational and democratic government. Therefore, considering democracy as a form of government, he argues for a democratic theory that must be closely linked to the processes through which rational citizens exert some control over the leaders of their own choosing.

As democracy for Dahl is an ideal, he prefers to use the concept polyarchy, i.e, the rule of many, to characterize the political system that derives from suffrage and guarantees equal and fair freedoms and opportunities for citizens. Therefore, when designing democracy, he is referring to one from a normative perspective, and when he is referring to the practice of the democratic regime, uses the concept of polyarchy [13].

Downs's thought is also important and has greatly contributed to the formation of modern democracies by considering that the political arena is regarded as an economic and financial market where individuals hold a rationality and behave accordingly. These elements contribute to the perception that voters behave like consumers, maximizing their gains and benefits on the one hand, and politicians as products, maximizing support for political agendas on the other.

Downs advances some conditions for a government to be considered as democratic. He starts that is needed a existence of a party that wins periodic elections; the existence of two or more parties competing for control of the government, and the right of any party to receive support from the majority of the voters, and to assume government powers until the next election [14].

Therefore, the thought of these three theorists is essential not only for the constitution of modern states, but also for the foundation of current democracies. Joseph Schumpeter thinks on democracy not as an end itself, but as a method of selecting ruling elites through elections. Dahl, in his conception of an elitist theory of power, conceives of democracy as a polyarchy, i.e, a form of democracy that reconciles participation and opposition in the political regime. Downs therefore conceives democracy using the economic model, and advances a pluralistic conception of power by using the economic theory of democracy to show that agents know how to order their preferences by using an 
instrumental rationality in their decisions.

These elements contribute to the perception that how important the Schumpeter, Dahl and Downs thought was not only for the formation and constitution of the modern democracies, but also to make modern democracies truly representative in the sense of building political regimes capable of responding to all the demands of society at various levels.

\section{Conclusion}

This article draws the conclusion that both Schumpeter, Dahl and Downs, in all their works, although democracy and power are not their special object of study, all somehow conceived the notions of democracy.

With the notions of democracy presented here, it can be inferred that in Schumpeter, democracy is a method that is used to achieve partisan interests. Thus, it is a political and institutional method used for political decision-making, which is effected through the competitive struggle for power in choosing leadership through free and periodic elections, and therefore legitimizes competition for leadership.

Dahl, in his view, argues that democracy leads the government to be responsive to its citizens, in order to guarantee certain opportunities for citizens in order to legitimize competition and citizens' rights. Therefore, democracy as ideal, never actually existed, and is an approach to the democratic ideal linked to competition and participation, which he calls polyarchy. Therefore, citizens have rationality and preferences protected by democratic institutions in order to consider their rights and interests for the formation of public policies.

For Downs, democracy makes the government act in accordance with its interests in order to reach power, and in this sense, elections have the role of selecting the government. Therefore, in its theoretical model of democracy, although individuals have an instrumental rationality, and use democracy based on the economic model, government is composed of people who have economic resources in order to formulate good action strategies to increase benefits and guarantee the right to vote of its citizens.

Therefore, it is inferred from this article that both Schumpeter, Dahl and Downs conceived a certain kind of democracy and / or power, which was important in the constitution and formation of modern democracies, making this article relevant.

\section{Acknowledgements}

This study was financed in part by the "Coordenação de Aperfeiçoamento de Pessoal de Nível Superior - Brasil (CAPES)" - Finance Code 001.

\section{References}

[1] Alcantara, Pedro Henrique (2017). The Elites against Democracy: The Minimalist Conception in the Hegemonic Field of Democratic Theory. Criticism and Society: magazine of political culture, Uberlândia, v. 7, no. 2, 2017.

[2] Centeno, Alison Ribeiro (2018). Confluences and Dissonances Between the theories of the democracy of Schumpeter and dahl: analysis of the criticism and some of their impacts. Rev. Field Notebooks | Macaw | no 25 | P. 139-156 | Jul. /Dec. 2018 | and ISSN 2359-2419.

[3] Steffens, Nikolay (2018). Debates in contemporary democratic theory: notes on the relationship between the market theories of politics and the principle of the natural identity of interests. Conjecture: Filos. Educ., V. 23, no. in particular, dossier Ethics and democracy. 2018, DOI: 10.18226 / 21784612.v23.dossie.6.

[4] Schumpeter, Joseph A. (1961). Capitalism, Socialism and Democracy. Rio de Janeiro: Culture Fund, pp, 296, 535, 355, 357.

[5] Silva, Pedro Gustavo de Sousa (2008). Democracy Theories: Contributions by Sartori, Dahl and Schumpeter. Urutagua Magazine. No. 15 - Apr./mai./jun./jul. 2008 - Quarterly Maringá - Paraná, p. 162.

[6] Miguel, Luís Felipe (2013). Democracy and Representation: Territories in Dispute. São Paulo: Unesp Publisher, p. 54.

[7] Weber, Max (1996). Science and Politics two Vocations. São Paulo: Cultrix.

[8] Costa, Homero de Oliveira (2007). Democracy and participation in pluralist theory. Kronos, Natal-RN, v. 8, no. 1, p. 215-228, jan./jun.

[9] Dahl, Robert A. (1957). The Concept of Power. Behavioral Science, 2: 3 (1957: July).

[10] Blokland, Hans (2016). Pluralism, Democracy and Political Knowledge: Robert A. Dahl and his critics on modern politics. New York: Routledge.

[11] Bachrach, Peter; BARATZ Morton S. (1962). Two Faces of Power. The American Political Science Review, Volume 56, Issue 4 (Dec. 1962), p. 947.

[12] Sieyès, E. M. [1788] (1988). The Bourgeois Constituent. What Is the Third State? (org. By A. W. Bastos). Rio de Janeiro: Liber Juris.

[13] Dahl, Robert A. (2005). Polyarchy: Participation and Opposition. São Paulo: Edusp, p. 26.

[14] Downs, Anthony (1999). An Economic Theory of Democracy. São Paulo: Edusp, pp. 28, 45, 293.

[15] Downs, Anthony (1957). An Economic Theory of Political Action in a Democracy. Journal of Political Economy, Vol. 65, No. 2 (Apr. 1957), p. 135-150. 